\title{
Irrigation response and water productivity of deficit to fully irrigated spring camelina
}

G. W. Hergerta, J.F. Margheima, A.D. Pavlista ${ }^{a}$, D. L. Martin ${ }^{b}$, T.A. Isbellc and R.J. Supalla ${ }^{b}$

a University of Nebraska-Lincoln, PREC, Scottsbluff, NE 69361, USA

b University of Nebraska-Lincoln, Lincoln, NE, 68583, USA

cUSDA-ARS, Peoria, IL 61604, USA

\section{Introduction}

Production of biofuel crops created major interest with the passage of the Energy Policy Act of 2005 (http://www.afdc.energy.gov/laws/epact_2005.html) which was extended and expanded by the Energy Independence and Security Act of 2007 (http://www.afdc.energy.gov/laws/eisa/). The bulk of energy research has focused on oil-seed crops as a biomass source for biodiesel production. Camelina [Camelina sativa L. Crantz] is an ancient crop that has been produced for many years in different parts of the world (Knorzer, 1978; Putnam et al., 1993). Recent interest in its potential as a biofuel (Bernardo et al., 2003; Frohlich and Rice, 2005; Moser and Vaughn, 2010; Zaleckas et al., 2012) and even as a jet fuel source (Shonnard et al., 2010) have been reviewed. Life cycle analysis of camelina as a biodiesel source shows its greenhouse gas emissions are $75-80 \%$ less than common petroleum fuels (Shonnard et al., 2010). Its high unsaturation levels of fatty acids result in poor oxidative stability which could limit camelina as a stand-alone biodiesel (Frohlich and Rice, 2005; Moser and Vaughn, 2010; Zaleckas et al., 2012). Blended camelina esters may be similar to soybean esters (Moser, 2010) and may be comparable to soybean biodiesel (Soriano and Narani, 2012). Part of the attraction of using camelina as a biofuel source is that it is considered a non-food crop, although camelina meal can be used as an animal feed (Pilgeram et al., 2007).

Camelina could be adapted for production in wheat-fallow rotations in the Great Plains of the USA (Aiken et al., 2015; Allen et al., 2014; Obour et al., 2015; Pavlista et al., 2011a; Schillinger et al., 2012). Research on camelina irrigation requirements are limited, with much of the research from Arizona using surface irrigation to achieve different levels of soil water depletion (French et al., 2009; Hunsaker et al., 2013). Pavlista et al. (2012) compared growth patterns of camelina to canola (Brassica napus) and brown mustard (Brassica juncea) under low irrigation. One of the limitations with shallow seeded camelina is germination under unpredictable spring precipitation in the Great Plains. If necessary, light irrigations at seeding facilitated improved germination and stand and make it a good candidate for limited irrigation (Aiken et al., 2015; Pavlista, et al., 2016a).

Temperature effects during camelina flowering have not been researched extensively and this could be a constraint for spring camelina as much of the initial research was in Montana (Pilgeram et al., 2007). Heat and moisture 
effects on oil seed crops, however, have been known for many years (Canvin, 1965). The effect of higher temperatures on reducing seed yield are often accentuated by reduced rainfall; however, the effect of reduced rainfall might be minimized by timely irrigation similar to canola (Kamkar et al., 2011).

Decreased ground water allocations (volumetric pumping restrictions) were initiated in 2004 for the northern High plains of western Nebraska (Bleed and Babbitt, 2015) and the need to determine water productivity response of potential biofuel crops was needed. Many areas of the High Plains have reduced irrigation amounts due to periodic drought (Basara et al., 2013), ground water pumping allocations (Bleed and Babbit, 2015) and reservoir supplies used for irrigation and aquifer recharge that are affected by a changing climate (Anderson and Woosley, 2005).

The concept of deficit irrigation has been known for many years (English, 1990 ) and has been researched as a production strategy on many conventional crops in Nebraska (Garrity et al., 1982; Hergert et al., 1993; Klocke, et al., Payero, et al., 2006; 1989; Schneekloth et al., 1991) and more recently on canola (Hergert et al., 2016; Pavlista et al., 2016b), but not camelina. The goal of deficit irrigation is to manage irrigation timing so the resulting water stress has less of a negative impact on grain yield.

The objectives of this research were to determine the effects of deficit to full irrigation on the yield, oil content, soil water changes and water productivity of spring camelina.

\section{Methods and materials}

This experiment was conducted during the growing seasons of 2007 through 2010. Spring camelina (cv. Cheyenne) was planted under linear irrigation systems at the Panhandle Research and Extension Center, Scottsbluff, NE $\left(41.89^{\circ} \mathrm{N}, 103.68^{\circ} \mathrm{W}\right)$ and the High Plains Ag Lab, Sidney, NE $\left(41.23^{\circ} \mathrm{N}\right.$, $\left.103.02^{\circ} \mathrm{W}\right)$. The soil at the Scottsbluff site was a Tripp very fine sandy loam (coarse-silty, mixed, superactive, mesic Aridic Haplustolls) whereas the soil at the Sidney location was a Keith silt loam (fine-silty, mixed, superactive, mesic Aridic Argiustolls). The slope at both sites ranged from $0.5 \%$ to $1 \%$. Other site characteristics are given in Table 1. Soil characteristics are for the top $30 \mathrm{~cm}$. Previous crops before camelina at Scottsbluff were dry beans (Phaseolus vulgaris) in 2006, 2007 and 2008 and potatoes (Solanum tuberosum L.) in 2009. Previous crops before camelina at the High Plains Ag Lab were proso millet (Panicum miliaceum L.) in 2006, 2007 and 2008 and winter wheat (Triticum aestivum L.) in 2009.

The plots were $7.6 \mathrm{~m}$ wide by $9.1 \mathrm{~m}$ long, with treatments replicated three times in a randomized complete block design. The irrigation system used was a Lockwood electric linear move with 5 spans $53 \mathrm{~m}$ in length with a Lindsay ${ }^{\mathrm{TM}}$ 
variable speed control panel. The system was plumbed with drops at $1.5 \mathrm{~m}$ spacing and nozzles located 1.4 to $1.5 \mathrm{~m}$ above ground level, each equipped with a manual turn off. The height of adjacent drops was varied (e.g., one at 1.4 $\mathrm{m}$ then the next at $1.5 \mathrm{~m}$, etc.) to reduce overlap interference with the spray pattern. The nozzles used on each drop were 3000 series 3T \#22 (Nelson Irrigation Corporation) that had maximum output of $10 \mathrm{I} \mathrm{min}^{-1}$. The irrigation system was operated at $207 \mathrm{KPa}$. This arrangement provided a spray pattern diameter of 5.5 to $6 \mathrm{~m}$ which provided low instantaneous application rates that allowed maximum time for infiltration and no runoff. The combination of variable speed and the ability to turn off every other nozzle allowed water applications from 2.5 to $38 \mathrm{~mm} \mathrm{hr}^{-1}$, however, regardless of water application amount, the system applied $10 \mathrm{~mm} \mathrm{hr}^{-1}$ which was below the soil's infiltration capacity.

Rain gauges were placed within plot areas to record irrigation and rainfall. Soil water content in 0 to $15 \mathrm{~cm}$ was determined gravimetrically every week, while water content at soil depths of $30,60,90,120$ and $150 \mathrm{~cm}$ was determined from weekly neutron probe measurements in each plot (503 DR Hydroprobe $\AA$, CPN International, Inc.). Neutron access tubes were installed two weeks after planting to allow evaluation of stand uniformity as camelina emergence required 7 to $14 \mathrm{~d}$ depending on yearly weather conditions. This allowed tube placement into similar stand uniformities and helped reduce spatial variability.

Planting and harvest dates are shown in Table 2. Sowing was early to midApril at rates of 3 to $3.5 \mathrm{~kg} \mathrm{ha}^{-1}$ of pure live seed (PLS) in 20-cm row spacing with a double-disc drill. A planting depth of $10 \mathrm{~mm}$ was targeted. Fertilization was based on expected yield, soil organic matter and nitrate- $\mathrm{N}$ tests using canola fertilizer guidelines (Boyles, et al., 2006) but $\mathrm{N}$ rates were reduced $30 \%$ based on the literature (Putnam, et al., 1993; Zubr, 1997). The residual nitrate level in most of the plots was high enough in most years that a preplant blanket application of $200 \mathrm{~kg} \mathrm{ha}^{-1}$ of ammonium sulfate (21-0-0 24S) provided sufficient $\mathrm{N}$ and $\mathrm{S}$. $\mathrm{P}$ and $\mathrm{K}$ levels were also high (above critical level) and no fertilizer was required.

The herbicide trifluralin (Treflan® HFP) at $1.2 \mathrm{I} \mathrm{ha-1}$ was soil incorporated preemergence for weed control. Plots were hand weeded as necessary and routinely scouted during the summer for insect damage; however, no significant insect problems were observed. Azoxystrobin (Quadris ${ }^{\circledR}$ ) at $0.73 \mathrm{I} \mathrm{ha}{ }^{-1}$ was used as a fungicide for downy mildew (Peronosporaceae) control during periods of $\mathrm{cool} /$ wet weather during 2009 and 2010. Disease was more severe at Sidney than Scottsbluff.

In many areas of the High Plains where ground water levels have declined or where pumping restrictions are enforced, producers who do not have enough water to meet full crop ET must use a different application and timing strategy than traditional full irrigation scheduling. Every rotation of a center pivot sprinkler increases cost, so if a producer can only apply $100 \mathrm{~mm}$ and they are not limited 
by well capacity, they will apply 5 irrigations of $20 \mathrm{~mm}$ rather than applying 10 irrigations of $10 \mathrm{~mm}$.

The irrigation timing used in this experiment was designed to prolong flowering and limit stress during seed fill. This strategy was patterned after canola (Faraji, et al., 2009; Gan et al., 2004; Hergert et al., 2016; Kamkar, et al., 2011). Previous research has shown that for most grain crops, applying limited water around flowering through early grain fill provides the greatest response to water (Anapalli et al., 2014; Hergert et al., 1993; Klocke et al., 1989). For the $100 \mathrm{~mm}$ treatment, irrigations were timed around early flowering through early grain fill. Depending on precipitation and the growing season, $60-70 \%$ of the total irrigation water was applied for each treatment during this time. The 200 $\mathrm{mm}$ treatment usually allowed irrigation from vegetative through mid- to late grain fill, depending on precipitation. The goal for this irrigation treatment was to apply $80 \%$ of the total water during this period. The $300 \mathrm{~mm}$ treatment allowed seasonlong irrigation that was based on weekly ET from water balance calculations. Irrigation application rates of 13 or $19 \mathrm{~mm}$ were used in this research to simulate expected producer practices. Our highest rate of $19 \mathrm{~mm}$ was applied over 2 hours and did not exceed the infiltration capacity of our soils. For higher weekly irrigation requirements (e.g., $40 \mathrm{~mm}$ ) biweekly irrigations were used.

Crop evapotranspiration (ET) was calculated every week for all plots at the two locations using the standard water balance equation as $E T=P+I-D P-R \pm \Delta S$ where $E T$ is evapotranspiration, $P$ is precipitation, I is applied irrigation, DP is deep percolation, $\mathrm{R}$ is surface runoff and $\Delta S$ is the weekly change in stored soil moisture. Values for precipitation, irrigation and changes in soil water content were measured or calculated for each replicate and averaged to compute a weekly water use (ET). No runoff was observed from plots after irrigation at either location. Adjustments were made for two precipitation events in 2009 and one in 2010 that did create runoff to calculate effective rainfall. Weekly water content at deeper soil depths did not show significant increases after the heavy rainfall events which indicated that deep percolation was negligible. Based on this, the equation was modified to $E T=P+$ $\mathrm{I} \pm \Delta \mathrm{S}$ for soil water balance calculations.

Seed harvest occurred in mid- to late July, depending on crop maturity at the two locations. To minimize potential yield losses associated with delayed harvest (i.e., pod shattering due to wind, rain, hail, and bird feeding) and to assure a yield value, plots were either harvested by hand and/or with a small-plot combine. An area $1 \mathrm{~m}$ by $1.2 \mathrm{~m}$ was hand harvested by placing clipped plants in fine plastic mesh drying bags when the majority of seeds had a moisture content of $12-14 \%$ and were subsequently air dried and hand threshed when seed moisture was approximately $10 \%$. Hand harvest occurred about a week to $10 \mathrm{~d}$ before combine harvest. Plots ( $1.2 \mathrm{~m}$ by $9 \mathrm{~m}$ area) were combine harvested when the majority of seeds had a moisture content of $8-10 \%$. All harvested seed samples were weighed for yield and analyzed for moisture (Dickey-John® GAC 2100 
Grain Analysis Computer).

Oil content was determined on samples for 2007 through 2010. Pulsed Nuclear Magnetic Resonance (pNMR) was used for total oil content. The analytical details are provided in Pavlista, et al., 2011b.

Seed yield and oil content from all sites and years was analyzed using the SAS software program PROC GLIMMIX (SAS Inst., 2014). Individual sites were analyzed using PROC GLM (SAS Inst., 2014) and Duncan's Multiple Range Test.

\section{Results}

3.1. Soil water content and rooting depth

Rainfall during the growing seasons (Table 3 ) varied substantially over the 4 years ranging from $35 \%$ to $128 \%$ of the long term average (NOAA, 2015) at Scottsbluff and from $87 \%$ to $172 \%$ at Sidney. This variability provided a wide range of conditions to determine plant growth and rooting depth from soil moisture extraction. Precipitation at Scottsbluff during 2007 and 2008 was well below the long term average. At Sidney, 2007 precipitation was near average and 2008 was below average. Precipitation was well above average at both locations in 2009 and slightly above average in 2010 .

The weekly soil moisture measurements were used to develop soil water use patterns. Soil water contents at the beginning and end of a crop growing season at the various soil depths helped determine the degree and depth of rooting development within the soil. The 2008 growing season was drier than normal at Scottsbluff and the data was used to show soil water content changes/rooting. Similar data were collected for the Sidney location but not shown. The initial soil water content of the Scottsbluff soil in 2008 was just slightly below field capacity soon after planting (Fig 1 ). All treatments received two small irrigations of $6 \mathrm{~mm}$ each to assure uniform emergence. The nonirrigated camelina (Fig 1a.), was able to extract soil water to about $1.0 \mathrm{~m}$. The data show no significant water extraction below this depth. At both Scottsbluff and Sidney, a calcium carbonate/caliche layer at 1.2 to $1.5 \mathrm{~m}$ was dense enough that we could not install neutron access tubes any deeper.

Similar moisture extraction patterns were shown for the low and medium irrigation treatments that received 100 and $200 \mathrm{~mm}$ of water (Fig 1b and 1c). Most of the moisture extraction was from the top $60 \mathrm{~cm}$. For all irrigation treatments, , soil water content was near permanent wilting point at a volumetric water content of $0.10 \mathrm{~m}^{3} \mathrm{~m}^{-3}$ in the surface $15 \mathrm{~cm}$ layer. There was little change in soil water content below $60 \mathrm{~cm}$ in all irrigation levels. Volumetric water contents at depths below $60 \mathrm{~cm}$ were similar to preplant levels. Due to high ET demand, the "high irrigation" treatment received $356 \mathrm{~mm}$ of irrigation plus 135 
$\mathrm{mm}$ of rainfall at Scottsbluff during 2008. Sidney also showed moisture extraction/rooting depths near $1.0 \mathrm{~m}$.

\subsection{Seed yield}

Seed yield analysis (Table 4) showed that all main and interaction effects were significant, so seed yield data is shown by individual sites and years (Table 5). Yield of fully irrigated treatments were three to four-fold higher than the nonirrigated treatment during dry years of 2007 and 2008. During the wetter years (2009 and 2010 at Scottsbluff) there was no response to irrigation, however, other factors also influenced final yield.

Non-ET limited yields during 2007 and 2008 were good except for the Sidney location in 2008 which suffered hail damage. Yields in 2009 and 2010 were reduced significantly by weather and disease. Freezing temperatures across the region in 2010 on April 24 reached $-4.5^{\circ} \mathrm{C}$ when camelina was about 4 to $5 \mathrm{~cm}$ tall. Snow and cold temperature on May 11 and 12 also affected the crop. During June, all locations had moderate hail and hard rain. Downy mildew (Peronosporaceae) caused significant damage during the cool and wet weather during 2009 and 2010 (Harveson et al., 2011). Azoxystrobin (Quadris ${ }^{\circledR}$ ) applications helped somewhat at Scottsbluff, but disease severity at Sidney in 2009 may have required earlier and repeated fungicide application. In 2010 yield levels at Scottsbluff and Sidney were similar and there was a significant irrigation effect at Sidney.

3.3 Yield response to irrigation and evapotranspiration.

Seed yield as affected by irrigation for all years and locations differed by seasonal precipitation amounts. Data was divided into wet years and dry years, based on comparison to the long-term average precipitation (Table 3, Fig. 2). Yield versus irrigation for 2009 and 2010 did not show any relationship. Data for both locations during 2007 and 2008 showed a curvilinear response to increasing irrigation (Fig. 2). A quadratic model had a higher $\mathrm{R}^{2}(0.84)$ but was not statistically different than a simple linear model $\left(R^{2}=0.82\right)$. Maximum seed yields near $2,900 \mathrm{~kg} \mathrm{ha}^{-1}$ were reached.

ETc data for the growing season are shown in Table 6. Seed yield versus ET for spring camelina is shown in Fig. 3. The 2009 Sidney data were not included due to severe disease pressure and very low ETc and seed yields. The function is described by a linear regression with the slope and $\mathrm{x}$-intercept corresponding to water productivity and a threshold water use value. The water production function for camelina predicted a yield increase of $7.0 \mathrm{~kg} \mathrm{ha}^{-1}$ of seed for each $\mathrm{mm}$ of water use above the threshold amount required to produce the first unit of seed yield $(125 \mathrm{~mm})$. Camelina seed yields ranged from 578 to $2,865 \mathrm{~kg} \mathrm{ha}^{-1}$ with 200 to $526 \mathrm{~mm}$ of cumulative water use. 
Detailed plant growth data were taken from these plots (Pavlista et al., 2016a). Camelina seed was considered mature and ready for harvest when the pods desiccated and hardened, and the seed color changed from green to cinnamon orange. During the very dry 2008 growing season, the effect of different irrigation levels on maximum crop ET, the length of crop water use and effects on crop maturity were significant (Fig. 4). The physiological maturity dates for the different water levels were: $0 \mathrm{~mm}$ : 14 weeks after planting (WAP); $100 \mathrm{~mm}$ : $15 \mathrm{WAP} ; 200 \mathrm{~mm}: 16 \mathrm{WAP}$ and $300 \mathrm{~mm}: 17$ WAP. Although the maximum and total crop ET are directly related to increased levels of irrigation, each water use function exhibited "peak values" in water use at 9 to 11 weeks after planting. Thereafter, "peak" water use for each irrigation treatment continued for approximately 12 to $18 \mathrm{~d}$ before declining. Phenology data collected from camelina plots in Scottsbluff during 2007 and 2008, indicate that observed "peak" values in water use are associated with maximum vegetative growth and flowering (Pavlista et al., 2016a). Continued water use was related to pod and seed development. Maximum water use approached values for canola (Hergert et al., 2016) and maize (Payero et al., 2006) during the hot and dry conditions of 2007 and 2008.

Different irrigation treatments also significantly affected maturity dates (Fig. 4). There was about a 3 week difference between the maturity of the nonirrigated treatment and the $300 \mathrm{~mm}$ irrigation level. Camelina adapted to water deficits by reducing ET and maturing more rapidly. In contrast to 2008, the growing season of 2009 had above average rainfall, however, Downy mildew (Peronosporaceae) limited yields even though fungicide was applied as a control measure. Consequently, there was no significant difference between any of the irrigation levels for water use, crop development, maturity and yield. Maximum weekly water use was only $44 \mathrm{~mm}$ in 2009 due to limited growth from disease compared to $63 \mathrm{~mm}$ in 2008 when conditions were very favorable for growth.

\subsection{Oil Content}

Statistical analysis showed that all main and interaction effects were significant except for site by irrigation (Table 7), so data is shown by individual sites and years (Table 8). Oil content was low during the drier and warmer years of 2007 and 2008 compared to expected values of 32 to $38 \%$. Yield and oil content were increased by irrigation at all sites in 2007 and 2008 and oil was increased at all sites except Sidney. The total oil production (data not shown) increased with irrigation amount at both sites for both years. In 2009 and 2010 when rainfall was above average and temperatures were cooler, oil content was higher except at Sidney where there was significant disease.

\section{Discussion}

\subsection{Camelina Management}


Camelina is a recently cultivated crop in the High Plains and has not had the advantage of years of plant breeding improvement similar to spring canola (Obour et al, 2014). Yield potential of spring camelina with our climatic conditions was between 2600 to $2900 \mathrm{~kg} \mathrm{ha}^{-1}$. This is significantly higher than rainfed or dryland production in semi-arid climates (Getch and Johnson, 2015; Sintim et al., 2016b) or under irrigation in Arizona (French et al., 2009; Hunsaker et al., 2011; Hunsaker et al., 2013). Similar yields have been reported in Eastern Europe (Vollmann et al., 2007) and in Washington (Schillinger et al., 2012). Yield potential during above average precipitation years may be a problem because of disease. The 2009 growing season precipitation was exceptionally high and there were many cloudy, high relative humidity days which is uncommon for our semi-arid climate. We also experienced some hail and freezing temperatures in 2010 that limited yield when precipitation was only 15 to $17 \%$ above the longterm average.

A management difficulty with spring camelina is shallow seeding depth. The very small seed requires adequate soil moisture for about two weeks after planting to insure uniform germination and a good stand (Aiken et al., 2015; Obour et al., 2015; Pavlista et al., 2011a). In our sandy soils and semiarid climate, rainfall most years may not be sufficient to produce a good stand. One or two small irrigations of 5 to $7 \mathrm{~mm}$ was usually sufficient to insure a good stand.

Pod shattering was a problem when direct combine harvest was used. Comparison of early hand harvest with combine harvest ranged from $10 \%$ to $15 \%$ grain loss due to shattering which is similar to other research in this region (Sintim et al., 2016a). Genetic improvement could overcome this problem, but there is currently limited funding and biodiesel production has lagged from lack of US government action. If recent alternative oilseed crops are to compete for crop acreage, innovative and faster breeding improvement will be required (Runck et al, 2014) as well as research into weed control options. Disease severity (downey mildew) during 2009 and 2010 was more pronounced on camelina than canola at our locations (Hergert et al., 2016). For canola, years of genetic improvement have created cultivars that have resistance to a number of diseases. Camelina has also shown resistance to a number of diseases (Eynck et al., 2013), but it has not been grown widely enough to test that natural resistance. Camelina showed more resistance to flea beetle (Phyllotreta sp.) than canola in our research (Hergert et al., 2016). The complete package of supporting agronomic traits and practices are still being developed for camelina.

\subsection{Soil Water Use}

Camelina showed soil water withdrawal to 0.9 to $1.0 \mathrm{~m}$ usually reaching those depths midway through flowering. Most of the soil water depletion was in the top $60 \mathrm{~cm}$. These are somewhat shallower than rooting depths shown for canola in the Great Plains (Gan, et al., 2009; Hergert et al., 2016; Merrill, et al., 2002; Nielsen, 1997) or Arizona (Hunsaker et al., 2013) but similar to winter 
camelina (Gesch and Johnson, 2015). Camelina also did not deplete soil water during the season as much as spring canola (Hergert, et al., 2016) throughout the soil profile. This may again be a reflection of less vigor from limited genetic improvement.

The soil moisture extraction pattern was similar for both locations. Deep rooting and effective use of stored soil water are essential in deficit irrigated areas to extract deeper soil moisture to supplement seasonal precipitation and irrigation. Rotations in the High Plains that include dry beans, winter wheat, sugar beet (Beta vulgaris) and maize would usually provide sufficient deeper soil moisture from the previous crop to allow deficit irrigated production with a crop that can effectively extract that moisture from below 0.8 to $1 \mathrm{~m}$.

\subsection{Water Productivity}

Camelina showed significant response to irrigation in drier years. During higher rainfall years there was no response to irrigation. During 2009 and 2010 , response was affected not only by additional precipitation but freezing late spring temperatures and disease. In drier years, irrigation response was almost linear with maximum irrigation of 300 to $350 \mathrm{~mm}$ required for highest yield

Cumulative water use under non-limiting conditions showed maximum ETc of $450-500 \mathrm{~mm}$. This is about $100 \mathrm{~mm}$ less than for canola at this site (Hergert et al., 2016), however, canola yields were higher than camelina yields. The slope for the yield-ET line for camelina was $7.0 \mathrm{~kg} \mathrm{~mm}^{-1}$ whereas canola was $10 \%$ higher $\left(7.7 \mathrm{~kg} \mathrm{~mm}^{-1}\right)$. Hunsaker et al., (2013) showed values that were about half of this, but their air temperature during mid-season were much higher than the High Plains during the heat of our summer. Threshold water use for both crops was near $125 \mathrm{~mm}$. The ET values are similar to other published work on canola in this region (Nielsen, 1997).

There was a significant effect of deficit irrigation on crop response in terms of maximum water use and maturity (Fig. 4). Deficit irrigation significantly reduced maximum ET and also accelerated maturity. The additional ET from the fully irrigated treatment versus lower irrigation amounts allowed additional biomass production which ultimately resulted in more yield (Pavlista et al., 2016). With good stand establishment and with average precipitation in this region, spring camelina could be an option for deficit irrigation as applying 60 to $70 \%$ of full irrigation would provide good yields.

There was a wide range in oil content during this experiment and it was significantly influenced by yearly weather and disease. This effect has been known for many years in Canadian canola production areas (Canvin, 1965). The range of oil content is consistent with other US research (French et al., 2009; Hunsaker et al., 2013) and other areas of the world (Berti et al., 2011; Vollmann et al, 2007). Because we experienced a wide range of weather conditions over 
the four years of the study, we were able to observe the impact of different conditions on camelina oil production in the High Plains. In drier years when temperatures during seed filling were higher, oil content was increased by irrigation but not to levels above $30 \%$. Alleviation of water stress can compensate somewhat for higher temperatures, but not totally. The economic benefit of the increased oil production compared to the increased cost of the irrigation could be calculated to determine break even irrigation values. The impact of disease at Sidney in 2009 shows its damaging effects on oil content. Economically, this is an important fact as producers consider deficit irrigation of camelina. During the very wet year of 2009 , which also had cooler summer temperatures, there was no effect of irrigation and oil content was high. In 2010, temperatures during grain fill were ideal and oil content was very high.

\section{Conclusions}

The rooting depth of camelina in both fine textured and sandy soils in western NE is sufficient to make it a viable alternative for deficit irrigation. Most of the rainfall in the northern High Plains occurs in spring (May and June). Precipitation plus limited irrigation at critical times provides an opportunity for camelina to use moisture stored in the lower part of the soil, but it does not root as deeply as canola. This is somewhat of a limitation that will need to be overcome by genetic improvement if commercial production is developed.

Camelina seed yield was sufficiently high during the varied precipitation conditions throughout the four years of this study to show its production potential which match that of other regions in the world. The yield potential in this region with irrigation was significantly higher than has been reported in most rainfed areas in the US (Gesch and Johnson, 2015; Hunsaker et al, 2013; Sintim et al, $2016 \mathrm{a}, 2016 \mathrm{~b}$ ). Applying 210 to $250 \mathrm{~mm}$ of irrigation in drier years which would be $60 \%$ to $70 \%$ of fully irrigated conditions produced yields of $78 \%$ and $87 \%$ of maximum. At these irrigation levels in drier years the additional water also increased oil content. Deficit irrigation decreased peak water use compared to non-ET limiting conditions and also hastened maturity. However, proper timing of deficit irrigation during flowering to early grain fill during severe moisture stress years produced significantly more yield than the non-irrigated treatment.

Natural Resource Districts in western NE are currently allowing yearly allocations of between 300 and $350 \mathrm{~mm}$ of irrigation (Bleed and Babbitt, 2015). Applying only $50 \%$ to $70 \%$ of the irrigation allotment would make deficit irrigated camelina an attractive lower water use cropping option when grown in rotation with higher water requiring crops. The additional benefits of not only higher yield, but also higher oil content makes deficit irrigated camelina a possible biofuel crop for this region.

\section{Acknowledgements}


Funding for this project was provided by the USDA Risk Management Agency under several contracts. Without their support we could not have completed this research.

\section{References}

Aiken, R., Baltensperger, D., Krall, J., Pavlista, A., Johnson, J. 2015. Planting methods affect emergence, flowering and yield of spring oilseed crops in the U.S. central High Plains. Ind. Crops Prod. 69:273-277.

Allen, R.G., Pereira, L.S., Raes, D., Smith, M., 1998. Crop EvapotranspirationGuidelines for Computing Crop Water Requirements. Irrigation and Drainage Paper No. 56. Food and Agriculture Organization of the United Nations (FAO), Rome, Italy.

Anderson, M.T and L.H. Woosley. 2005. Water availability for the western United States: key scientific challenges. US Geological Survey Circular 1261, $85 \mathrm{p}$.

Anapalli, S.S., T. Trout, L.R. Ahuja, L. Ma, G.S. McMaster and D.C. Nielsen. 2014. Quantifying crop water stress factors from soil water measurements in a limited irrigation experiment. Agric. Systems 137:191-205. DOI: 10.1016/j.agsy.2014.11.005.

Basara, J.B., Maybourn, J.N., Peirano, C.M., Tate, J.E., Brown. P.J., Hoey, J.D., Smith, B.R. 2013. Drought and associated impacts in the Great Plains of the United States - A review. Intl. J. Geosci. 4:72- 25681.

Bernardo, A., Howard-Hildige, R., O'Connell, A., Nichol, R., Ryan, J., Rice, B., Roche, E., Leahy, J.J. 2003. Camelina oil as a fuel for diesel transport engines. Ind. Crops Prod. 17:191-197.

Berti, M., R. Wilckens, S. Fischer, A. Solis and B. Johnson. 2011. Seeding date influence on camelina seed yield, yield components, and oil content in Chile. Ind. Crop Prod. 34: 1358 - 1365.

Bleed, A. and C. H. Babbitt. 2015. Nebraska's Natural Resources Districts: An assessment of a large-scale locally controlled water governance framework. Policy Report 1, Robert B. Daugherty Water for Food Institute, Univ. of NELincoln, $155 \mathrm{pp}$.

Boyles, M, T. Peeper and M. Stamm. 2006. Great Plains Canola Production Handbook. Kansas State U. MF-2734. 
Canvin, D.T. 1965. The effect of temperature on the oil content and fatty acid composition of the oils from several oil seed crops. Can. J. Botany 43: 6269.

English, M. 1990. Deficit irrigation. I: Analytical framework. Journ. Irrig. Drain. E.ASCE 116, 399-412.

Eynck, C., D. Shrestha, J. Vollmann, K.C. Falk, W. Friedt, H.P Singh and E. Obeng. 2013. Sustainable oil crops production. In, B.P Singh (ed.) Biofuel Crop sustainability. John Wiley \& Sons, Inc.

French, A.N., Hunsaker, D., Thorp, K., Clarke, T. 2009. Evapotranspiration over a camelina crop at Maricopa, Arizona. Ind. Crops Prod. 29:289-300.

Frohlich, A., Rice, B. 2005. Evaluation of Camelina sativa oil as a feedstock for biodiesel production. Ind. Crops Prod. 21:24-31.

Gesch, R.W. and J. M.-F. Johnson. 2015. Water use in camelina-soybean dual cropping systems. Agron. J. 107: 1098 - 1104.

Harveson, R.M., D.K. Santra, A.D. Pavlista, M.L. Putnam, and M. Curtis. (2011). A New Report for Downy Mildew (Hyaloperonospora camelinae Gäum.) Göker, Voglmayr, Riethm., M. Weiss \& Oberw.) of Camelina (Camelina sativa (L.) Crantz in the High Plains of the United States. Plant Health Progress doi: 10.1094/PHP-2011-1014-01-BR.

Hergert, G.W., N.L Klocke, J.L. Petersen, P.T. Nordquist, R.T. Clark and G.A. Wicks. 1993. Cropping systems for stretching limited irrigation supplies. J. Prod. Agric. 6, 520-528.

Hergert, G.W., J.F. Margheim, A.D. Pavlista, D.L. Martin, R.J Supalla and T.A. Isbell. 2016. Deficit to fully irrigated spring canola yield, irrigation response and evapotranspiration. Agric. Water Mgmt. 106: 96 - 103. doi:10.1016/j.agwat.2016.02.003.

Hunsaker, D.J., French, A.N., T.R. Clark and D.M. El-Shikha. 2011. Water use, crop coefficients, and irrigation management criteria for camelina production in arid regions. Irrig. Sci. 29: 27 - 43. 
Hunsaker, D.J., A.N. French, and K.R. Thorp. 2013. Camelina water use and seed yield response to irrigation scheduling in an arid environment. Irrig. Sci. 31:911-929.

Kamkar, B., A.R. Daneshmand, F. Ghooshchi, A.H. Shiranirad and A.R. Safahani Langeroundi. 2011. The effects of irrigation regimes and nitrogen rates on some agronomic traits of canola under a semiarid environment. Ag. Water Mgmt. 98: 1005-1012.

Klocke, N.L., D.E. Eisenhauer, J.E. Specht, R.W. Elmore and G.W. Hergert. 1989. Irrigation soybean by growth stages in Nebraska. Applied Eng. In Agric. 5:361-366.

Merrill, S.D., D.L. Tanaka, and J.D. Hanson. 2002. Root length growth of eight crop species in Haplustoll soils. Soil Sci. Soc. Am J. 66: 913 - 923.

Knorzer, K.H. 1978. Evolution and spread of Gold of Pleasure (Camelina sativa S.L.). Bererichte der Deutschen Botanischen Gesellschaft 91: 187-195).

Moser, B.R. 2010. Camelina (Camelina sativa L.) oil as a biofuel feedstock: Golden opportunity or false hope? Lipid Tech. 22:270-273.

Moser, B.R. and Vaughn, S.F. 2010. Evaluation of alkyl esters from Camelina sativa oil as biosiesel and as blend components in ultra-low sulfur diesel fuel. Bioresource Tech. 101:646-653.

Obour, A.K., Sintin, H.V., Obeng, E., Jeliazkov, V.D. 2015. Oilseed camelina (Camelina sativa L.Crantz): Production systems, prospects and challenges in the USA Great Plains. Adv. Plants Agric. Res. 2:1-10.

Pavlista, A.D., D D. Baltensperger, T.A. Isbell and G.W. Hergert. 2012. Comparative growth of spring-planted canola, brown mustard and camelina. Ind. Crops Prod. 36: 9-13.

Pavlista, A.D., G.W. Hergert, J.M. Margheim, and T.A. Isbell. 2016a. Growth of spring camelina (Camelina sativa) under deficit irrigation in western Nebraska. Ind. Crops and Products 83:118-123. doi:10.1016/j.indcrop. 2015.12.017.

Pavlista, A.D., G.W. Hergert, J.M. Margheim, and T.A. Isbell. 2016b. Growth of spring canola (Brassica napus) under deficit irrigation in western Nebraska. Ind. Crops and Products 83: 635-640. doi:10.1016/j.indcrop. 2015.12.059. 
Pavlista, A.D., T.A. Isbell, D D. Baltensperger, and G.W. Hergert. 2011a. Planting date and development of spring-seeded irrigated canola, brown mustard and camelina. Ind. Crops Prod. 33:451-456.

Pavlista, A.D., D. K. Santra, T.A. Isbell, D D. Baltensperger, G.W. Hergert, J. Krall, A. Mesbach, J. Johnson, M. O'Neil, R. Aiken, A. Berrada. 2011b. Adaptability of irrigated spring canola oil production to the US High Plains. Industrial Crops and Products 33:165-169.

Payero, J.O., S.R. Melvin, S. Irmak and D.Tarkalson. 2006. Yield response of corn to deficit irrigation in a semiarid climate. Ag. Water Mgmt. 84: 101-112.

Pilgeram, A.L., Sands, D.C., Boss, D., Dale, N. Wichman, D., Lamb, P., Lu, C., Barrows, R., Kirkpatrick, M., Thompson, B., Johnson, D.L. 2007. Camelina sativa, a Montana omega-3 and fuel crop. In: Janick, J., Whipkey, A. (ed.) Issues in New Crops and New Uses. ASHS Press, Alexandria, VA. pp. 129131.

Putnam, D.H., Budin, J.T., Field, L.A., Breene, W.M. 1993. Camelina: A promising low-input oilseed. In: Janick, J., Simon, J.E. (ed.) New Crops. Wiley, NY. pp. 314-322.

Runck, B.C., M.B. Kantar, N.R. Jordan, J.A. Anderson, D.L. Wyse, J.O. Eckberg, R.J. Barnes, C.L. Lehman, L.R. DeHaan, R.M. Stupar, C.C. Sheaffer, and P.M. Porter. 2014. The reflective plant breeding paradigm: A robust system of germplasm development to support strategic diversification of agroecosystems. Crop Sci. 54: 1939 - 1948.

SAS Institute, 2014. SAS System for Windows. Release 9.4. SAS Institute Inc., Cary, NC.

Schneekloth, J.P., N.L. Klocke, G.W. Hergert, D.L. Martin and R.T. Clark. 1991. Crop rotations with full and limited irrigation and dryland management. Trans. ASAE 34(6): 2372-2380.

Schillinger, W.F., Wysocki, D.J., Chastain, T.G., Guy, S.O., Karow, R.S. 2012. Camelina: Planting date and method effects on stand establishment and seed yield. Field Crops Res. 130:138-144. 
Shonnard, D.R., Williams, L., Kalnes, T.N. 2010. Camelina-derived jet fuel and diesel: Sustainable advanced biofuels. Environ. Prog. Sustain. Energy 29:382-392.

Sintim, H.Y., V. D. Zheljazkov, A.K. Obour, and A. Garcia y Garcia. 2016a. Managing harvest time to control pod shattering in oilseed camelina. Agron. J. 108: $1-6$.

Sintim, H.Y., V. D. Zheljazkov, A.K. Obour, A. Garcia y Garcia, and T.K. Foulke. 2016b. Evaluating agronomic responses of camelina to seeding date under rain-fed conditions. Agron. J. 108: 349 - 357.

Soriano, N.U., Narani, A. 2012. Evaluation of biodiesel derived from Camelina sativa oil. J. Am. Oil Chem. Soc. 89:917-923.

Vollmann, J., T. Moritz, C. Kargl, S. Baumgartner, and H. Wagentristl. 2007. Agronomic evaluation of camelina genotypes selected for seed quality characteristics. Ind. Crops Prod. 26:270 - 277.

Zaleckas, E., Makareviciene, V., Senzikiene, E. 2012. Possibilities of using Camelina sativa oil for producing biodiesel fuel. Transport 27:60-66.

Zubr, J. 1997. Oil-seed crops: Camelina sativa. Ind. Crops Prod. 6: 113-120. 
Table 1. Site characteristics for the two camelina locations for the top $20 \mathrm{~cm}$.

\begin{tabular}{|c|c|c|c|c|c|c|}
\hline \multirow[t]{3}{*}{ Location } & Elevation & Annual & $\mathrm{pH}$ & Organic & $\ominus v$ & $\Theta v$ \\
\hline & & Precipitation & & Matter & Field & Wilting \\
\hline & & & & & Capacity* & Point ${ }^{*}$ \\
\hline Scottsbluff & $1189 \mathrm{~m}$ & $394 \mathrm{~mm}$ & 8.2 & $1.5 \%$ & $0.23-0.28 \mathrm{~m}^{3} \mathrm{~m}^{-3}$ & $0.11 \mathrm{~m}^{3} \mathrm{~m}^{-3}$ \\
\hline Sidney & $1247 \mathrm{~m}$ & $404 \mathrm{~mm}$ & 7.5 & $2.2 \%$ & $0.25-0.31 \mathrm{~m}^{3} \mathrm{~m}^{-3}$ & $0.13 \mathrm{~m}^{3} \mathrm{~m}^{-3}$ \\
\hline
\end{tabular}

* National Cooperative Soil Survey

National Cooperative Soil Survey Characterization Database

http://ncsslabdatamart.sc.egov.usda.gov/

Accessed Thursday, June 02, 2016 
Table 2. Camelina planting and harvest dates.

\begin{tabular}{|c|c|c|c|c|c|}
\hline \multirow[t]{2}{*}{ Site } & \multicolumn{5}{|c|}{ Years } \\
\hline & & 2007 & 2008 & 2009 & 2010 \\
\hline \multirow[t]{2}{*}{ Scottsbluff } & Sowing & $15 \mathrm{Apr}$ & $8 \mathrm{Apr}$ & $10 \mathrm{Apr}$ & $9 \mathrm{Apr}$ \\
\hline & Harvest & $24 \mathrm{Jul}$ & $24 \mathrm{Jul}$ & $20 \mathrm{Jul}$ & $8 \mathrm{Jul}$ \\
\hline \multirow[t]{2}{*}{ Sidney } & Sowing & $18 \mathrm{Apr}$ & $16 \mathrm{Apr}$ & $8 \mathrm{Apr}$ & $12 \mathrm{Apr}$ \\
\hline & Harvest & $18 \mathrm{Jul}$ & $25 \mathrm{Jul}$ & $13 \mathrm{Jul}$ & $14 \mathrm{Jul}$ \\
\hline
\end{tabular}


Table 3. Growing season precipitation* at the two plot locations (April to harvest).

\begin{tabular}{|c|c|c|c|c|c|c|}
\hline \multirow[t]{2}{*}{ Site } & & \multicolumn{5}{|c|}{ Years } \\
\hline & & 2007 & 2008 & 2009 & 2010 & $30 \mathrm{y}$ avg \\
\hline \multirow[t]{5}{*}{ Scottsbluff } & Apr & 29 & 17 & 65 & 66 & 43 \\
\hline & May & 30 & 57 & 47 & 83 & 84 \\
\hline & Jun & 8 & 38 & 149 & 110 & 71 \\
\hline & Jul & 12 & 23 & 31 & 9 & 30 \\
\hline & Total & 79 & 135 & 292 & 268 & 228 \\
\hline \multirow[t]{5}{*}{ Sidney } & Apr & 94 & 35 & 96 & 63 & 36 \\
\hline & May & 75 & 66 & 41 & 59 & 71 \\
\hline & Jun & 50 & 76 & 252 & 102 & 74 \\
\hline & Jul & 11 & 32 & 21 & 50 & 58 \\
\hline & Total & 230 & 209 & 410 & 274 & 239 \\
\hline
\end{tabular}

${ }^{*}$ NOAA, 2015. http://www.ncdc.noaa.gov/cdo-web/. 
Table 4. Analysis of variance of camelina yield over all years.

\begin{tabular}{lc}
\hline Effect & Prob $>\mathrm{F}$ \\
\hline Site & $<0.01$ \\
Irrigation & $<0.01$ \\
Site x irrigation & 0.01 \\
Year & $<0.01$ \\
Site x year & $<0.01$ \\
Irrigation x year & $<0.01$ \\
\hline
\end{tabular}


Table 5. Camelina seed yield $\left(\mathrm{kg} \mathrm{ha}^{-1}\right)$ at different irrigation treatments for different locations 2007 through 2010.

\begin{tabular}{|c|c|c|c|c|c|}
\hline & & 2007 & 2008 & 2009 & 2010 \\
\hline Site & Irrigation-mm & & & & \\
\hline \multirow[t]{4}{*}{ Scottsbluff } & 0 & $833 d$ & $768 d$ & $1574 a$ & $1036 a$ \\
\hline & 100 & $1356 c$ & $1495 c$ & $1481 a$ & $1159 a$ \\
\hline & 200 & $2004 b$ & $2139 b$ & $1575 a$ & $1144 a$ \\
\hline & 300 & $2587 a$ & $2867 a$ & $1608 a$ & $1146 a$ \\
\hline \multicolumn{6}{|l|}{ Irrg effect } \\
\hline $\operatorname{Pr}>\mathrm{F}$ & & 0.01 & 0.01 & 0.29 & 0.35 \\
\hline CV & & $6.5 \%$ & $10.8 \%$ & $7.1 \%$ & $6.6 \%$ \\
\hline \multirow[t]{4}{*}{ Sidney } & 0 & $1147 c$ & $578 c$ & 428a† & $644 \mathrm{c}$ \\
\hline & 100 & $1952 b$ & $1330 b$ & $446 a$ & $741 \mathrm{c}$ \\
\hline & 200 & $2521 a$ & $1661 a$ & $449 a$ & $937 b$ \\
\hline & 300 & $2671 a$ & $1931 a$ & $457 a$ & $1120 a$ \\
\hline \multicolumn{6}{|l|}{ Irrg effect } \\
\hline $\operatorname{Pr}>\mathrm{F}$ & & 0.01 & 0.01 & 0.57 & 0.01 \\
\hline $\mathrm{CV}$ & & $6.0 \%$ & $11.7 \%$ & $5.2 \%$ & $8.6 \%$ \\
\hline
\end{tabular}

*Values followed by the same letter are not significantly different at the $\mathrm{P}<0.05$ level based on least significant differences; $\mathrm{NS}=$ non-significant at $\mathrm{P}<0.05$.

† Plot had severe disease. 
Table 6. Soil water balance data (ETc) for the Scottsbluff (SB) and Sidney (HP) locations.

\begin{tabular}{|c|c|c|c|c|c|}
\hline Year & Site & Rainfall & Irrigation & $\Delta$ Soil water & ETc \\
\hline 2007 & SB & 66 & 15 & -99 & 180 \\
\hline 2007 & SB & 66 & 102 & -109 & 277 \\
\hline 2007 & SB & 66 & 203 & -102 & 371 \\
\hline 2007 & SB & 66 & 305 & -89 & 460 \\
\hline 2007 & $\mathrm{HP}$ & 221 & 15 & -64 & 300 \\
\hline 2007 & $\mathrm{HP}$ & 221 & 89 & -51 & 361 \\
\hline 2007 & HP & 221 & 203 & -51 & 475 \\
\hline 2007 & $\mathrm{HP}$ & 221 & 262 & -3 & 485 \\
\hline 2008 & SB & 112 & 15 & -86 & 213 \\
\hline 2008 & SB & 112 & 107 & -64 & 282 \\
\hline 2008 & SB & 135 & 216 & -51 & 401 \\
\hline 2008 & SB & 137 & 356 & -33 & 526 \\
\hline 2008 & HP & 145 & 15 & -41 & 201 \\
\hline 2008 & $\mathrm{HP}$ & 145 & 114 & -41 & 300 \\
\hline
\end{tabular}




$\begin{array}{llllll}2008 & \text { HP } & 145 & 203 & -28 & 376 \\ 2008 & \text { HP } & 145 & 267 & -30 & 442 \\ 2009 & \text { SB } & 292 & 20 & -33 & 345 \\ 2009 & \text { SB } & 292 & 33 & -3 & 328 \\ 2009 & \text { SB } & 292 & 43 & -5 & 340 \\ 2009 & \text { SB } & 292 & 43 & -3 & 338 \\ & & & & & \\ 2009 & \text { HP } & 318 & 18 & 69 & 267 \\ 2009 & \text { HP } & 325 & 38 & 94 & 269 \\ 2009 & \text { HP } & 325 & 51 & 86 & 290 \\ 2009 & \text { HP } & 325 & 51 & 94 & 282 \\ 2010 & & & & & \\ 2010 & \text { SB } & 218 & 13 & -76 & 307 \\ 2010 & \text { SB } & 218 & 58 & -51 & 328 \\ 2010 & \text { SB } & 218 & 94 & -30 & 343 \\ 2010 & \text { SB } & 218 & 94 & -30 & 343 \\ 2010 & \text { HP } & 244 & 38 & 3 & 279 \\ 2010 & \text { HP } & 244 & 74 & 3 & 315 \\ 2010 & \text { HP } & 244 & 74 & -3 & 320\end{array}$


Table 7. Analysis of variance of camelina oil content over all sites.

\begin{tabular}{lc}
\hline Effect & Prob $>\mathrm{F}$ \\
\hline Site & 0.01 \\
Irrigation & 0.01 \\
Site x irrigation & 0.38 \\
Year & $<0.01$ \\
Site x year & $<0.01$ \\
Irrigation x year & $<0.05$ \\
& \\
\hline
\end{tabular}


Table 8. Camelina oil content (\%) for different locations 2007 through 2010.

\begin{tabular}{lccccc}
\hline \multicolumn{5}{c}{ Year } & \multicolumn{5}{c}{2007} & 2008 & 2009 & 2010 \\
\hline Site & Irrigation-mm & & & \\
Scottsbluff & 0 & $29.7 \mathrm{ab}$ & $25.7 \mathrm{c}$ & $38.6 \mathrm{a}$ & $41.1 \mathrm{a}$ \\
& 100 & $28.1 \mathrm{c}$ & $26.9 \mathrm{~b}$ & $40.3 \mathrm{a}$ & $42.8 \mathrm{a}$ \\
& 200 & $28.9 \mathrm{bc}$ & $27.4 \mathrm{~b}$ & $38.7 \mathrm{a}$ & $43.9 \mathrm{a}$ \\
& 300 & $30.1 \mathrm{a}$ & $28.6 \mathrm{a}$ & $38.8 \mathrm{a}$ & $44.2 \mathrm{a}$ \\
& & & & & \\
Irrg effect & & 0.02 & 0.01 & 0.19 & 0.57 \\
Pr>F & & $1.9 \%$ & $1.4 \%$ & $2.4 \%$ & $6.7 \%$ \\
$\mathrm{CV}$ & & & & \\
& & & & & \\
Sidney & 0 & $29.4 \mathrm{a}$ & $25.4 \mathrm{c}$ & $29.3 \mathrm{a}$ & $47.9 \mathrm{a}$ \\
& 100 & $29.9 \mathrm{a}$ & $25.7 \mathrm{c}$ & $29.2 \mathrm{a}$ & $47.2 \mathrm{a}$ \\
& 200 & $29.8 \mathrm{a}$ & $27.1 \mathrm{~b}$ & $29.2 \mathrm{a}$ & $49.8 \mathrm{a}$ \\
& 300 & $30.0 \mathrm{a}$ & $27.6 \mathrm{a}$ & $29.1 \mathrm{a}$ & $47.8 \mathrm{a}$ \\
Irrg effect & & & & & \\
Pr>F & & 0.41 & 0.01 & 0.99 & 0.30 \\
$\mathrm{CV}$ & & $1.4 \%$ & $1.0 \%$ & $3.7 \%$ & $3.3 \%$ \\
& & & & & \\
\hline
\end{tabular}

*Values followed by the same letter are not significantly different at the

$P<0.05$ level based on least significant differences; $N S=$ non-significant at $P<0.05$. 


\section{List of Figures}

Figure 1. Seasonal soil water content change at Scottsbluff, Nebraska during the dry year of 2008.

Error bars show \pm standard error of the mean.

Figure 2: Irrigation effect on camelina seed yield (2007-2008).

HP-07 and HP-08 were Sidney, NE locations in 2007 and 2008.

SB-07 and SB-08 were Scottsbluff, NE locations in 2007 and 2008.

Figure 3: Water use and seed yield for camelina (2007-2010).

HP-07, HP-08 and HP-10 were Sidney, NE locations in 2007, 2008 and 2010.

SB-07, SB-08, SB-09 and SB-10 were Scottsbluff, NE locations in 2007, 2008, 2009 and 2010.

Figure 4. Weekly crop water use for camelina at different irrigation levels at Scottsbluff, Nebraska in 2008. 


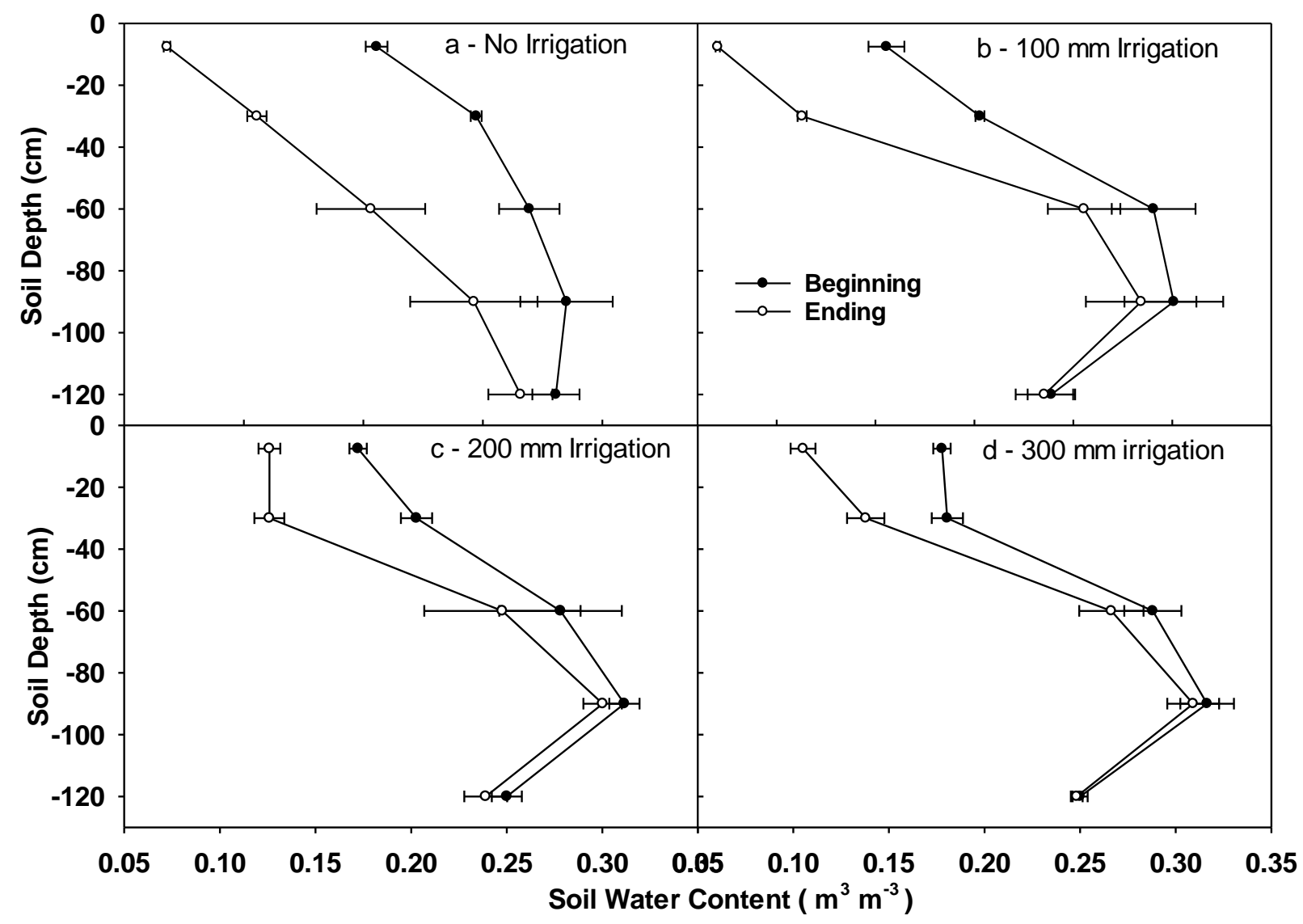




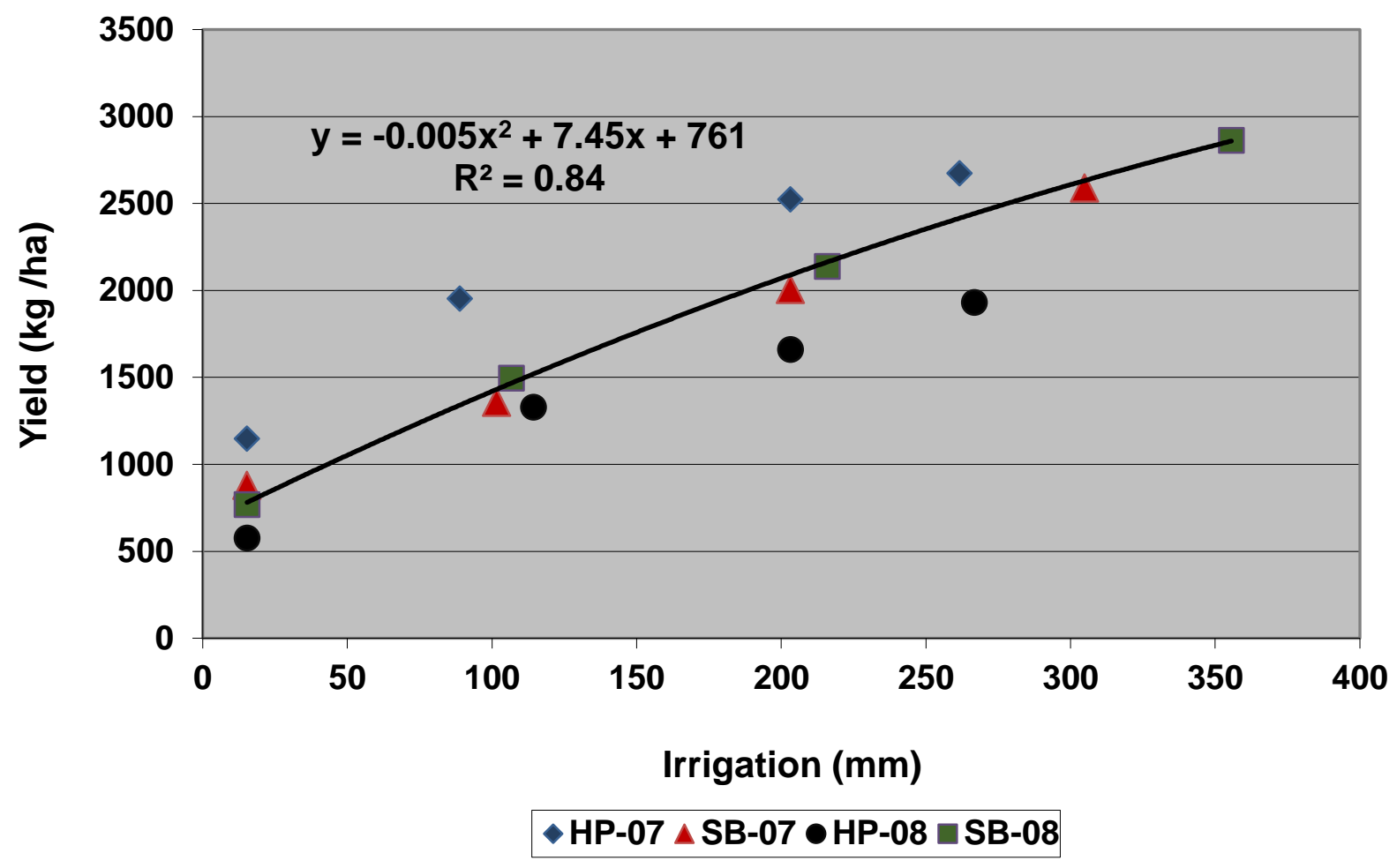




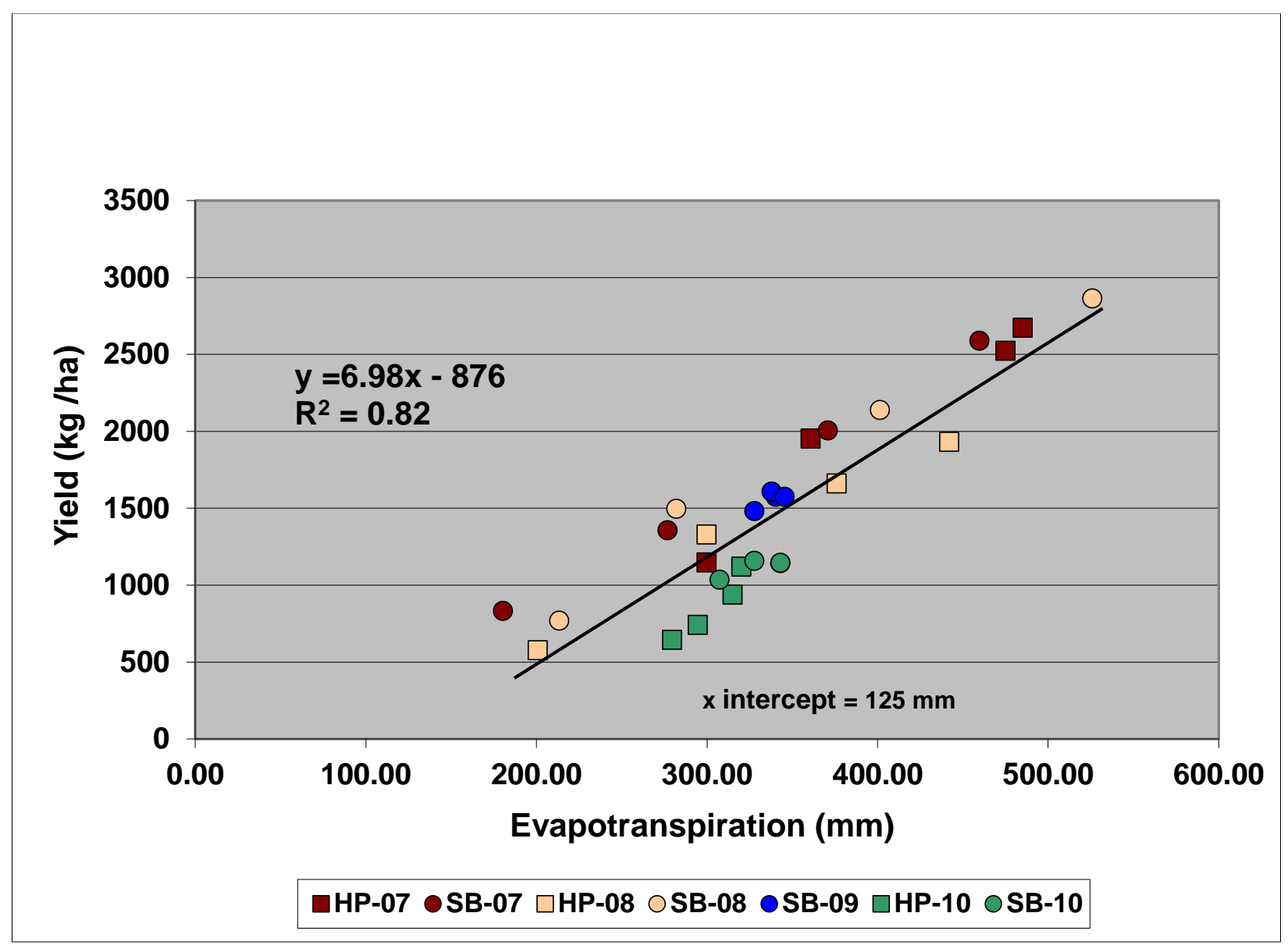




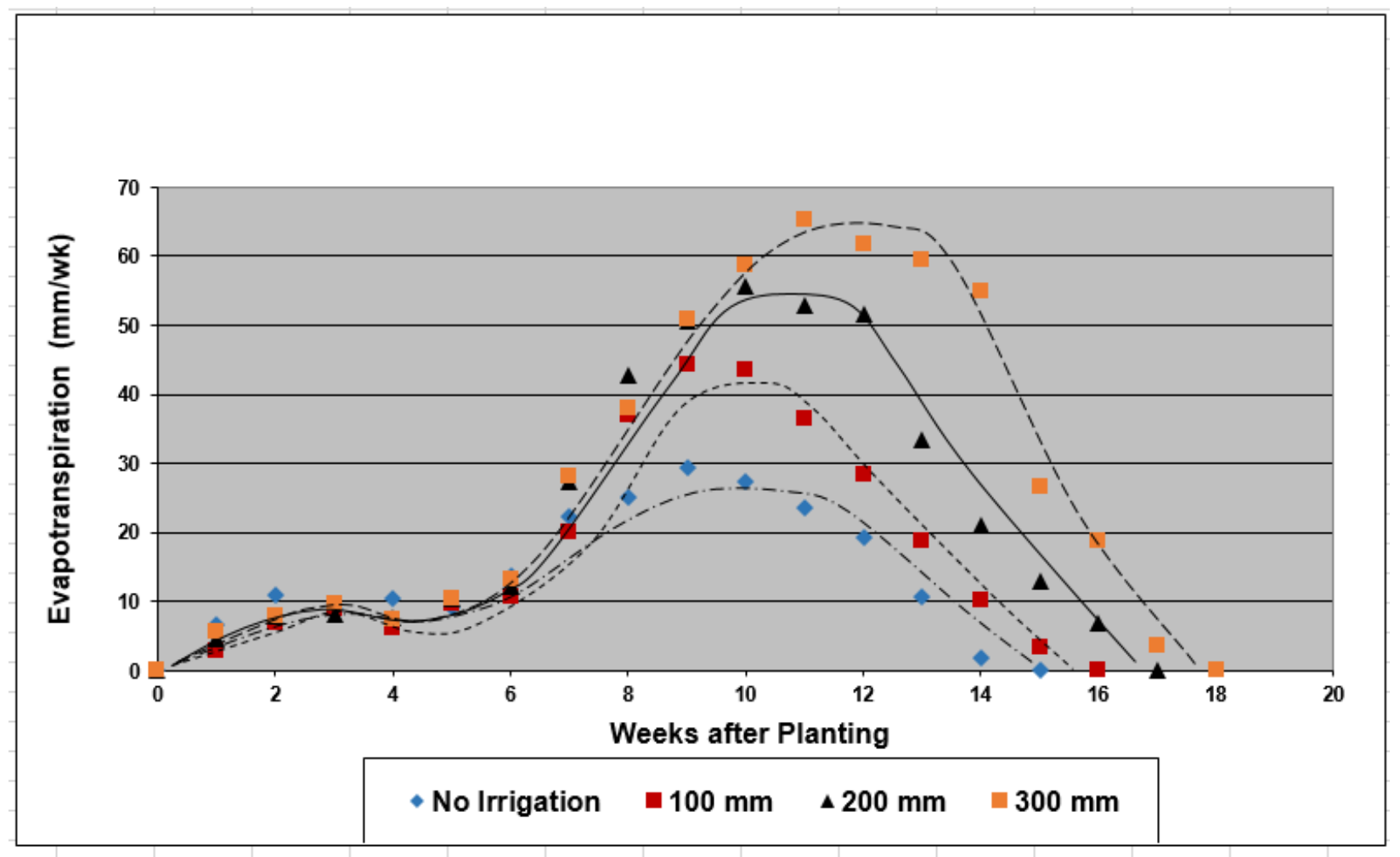




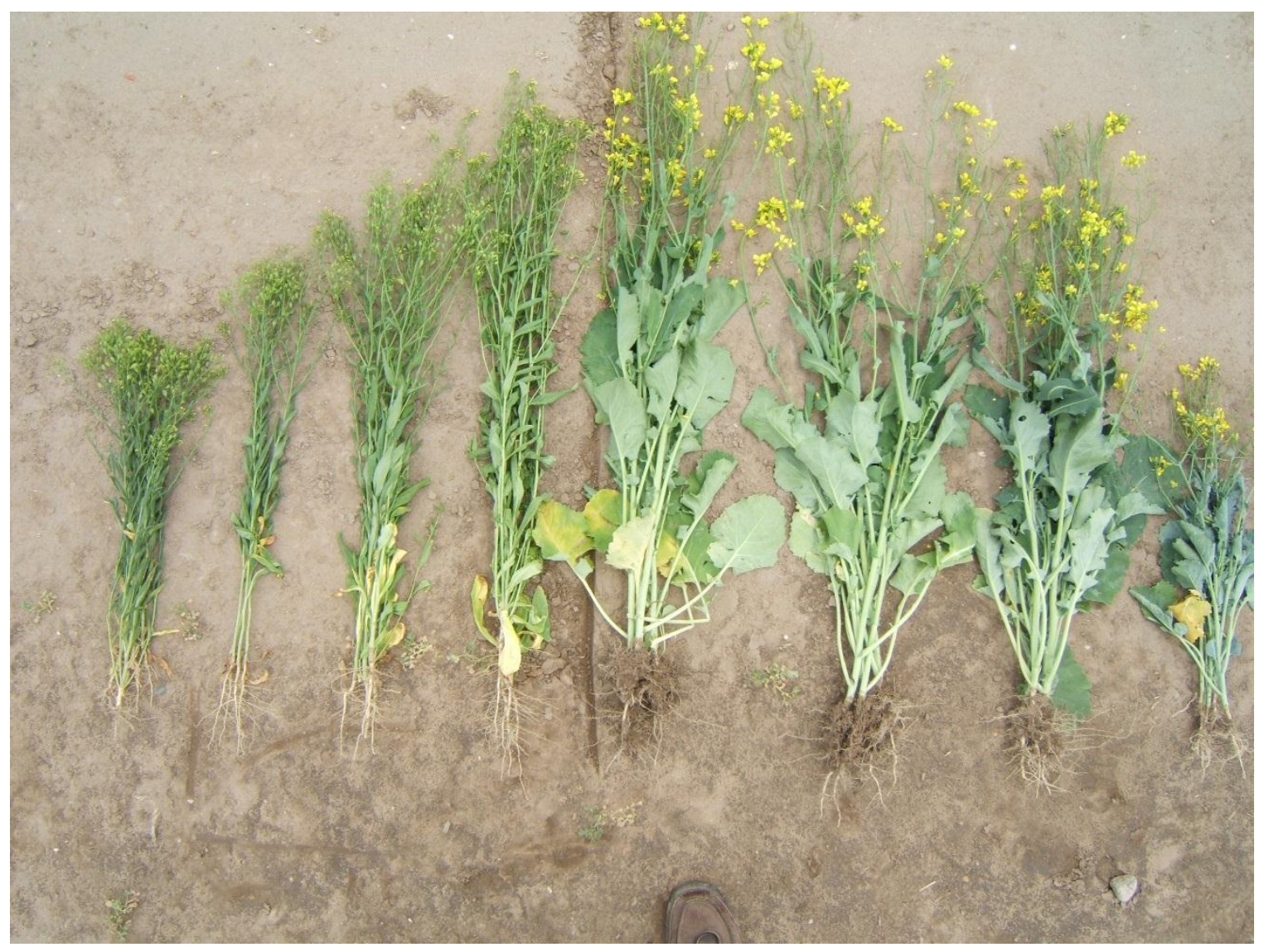


Graphical Abstract caption Rev3

Camelina is on the left and canola on the right side of the photo. The highest irrigation level is in the middle of the plant grouping with no irrigation on the ends. 